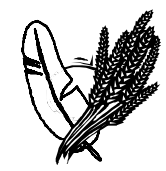

\title{
Рецензіï Reviews
}

\section{DOI: 10.31651/2413-8142-2019-22-66-67}

Масненко В. В. «Аграрне законодавство періоду Української революції (1917-1921 рр.) : збірник документів і матеріалів/ упоряд. : С. В. Корновенко, А. Г. Морозов, Ю. Г. Пасічна. - Черкаси : Чабаненко Ю.A., 2019 - 554 c.»*

Дослідники аграрної історії з Черкаського національного університету імені Богдана Хмельницького у рамках виконання держбюджетної теми «Українська революція (1917-1921 рр.): селянський фактор» (номер державної реєстрації 0112U003864) опублікували збірник документів і матеріалів, присвячений аграрному законодавству періоду Української революції. В цьому унікальному виданні представлено 140 нормативних актів законодавчого, розпорядчого, управлінського характеру, які достатньо репрезентативно характеризують аграрну політику різних державних утворень і політичних режимів на території України: Тимчасового уряду, Української Центральної Ради, Української Держави, Директорії УНР, ЗУНР, органів совєтської влади, Особливої наради ЗСПР, Уряду Півдня Росії, Другої Речі Посполитої, Румунії та Чехословаччини у 1917-1921 pp.

Збірник має логічно виправдану структуру, яка містить десять глав, матеріали у яких підібрано за хронологічним і хронологічно-тематичним принципом. Кожний документ має відповідну атрибуцію iз зазначенням місця архівного збереження, або його першої/попередньої публікації. Позитивною стороною збірника, яка визначає належний науковий рівень $є$ наявність довідкового апарату, що складається iз іменного та географічного покажчиків, переліку використаних архівних фондів та опублікованих документів, переліку письмових документів, списку скорочень і умовних позначень.

У виданні вміщено документи із фондів Центрального державного архіву вищих органів влади та управління України, Державного архіву Автономної Республіки Крим, Державного архіву Російської Федерації. Частина 3 них безпосередньо виявлена упорядниками і вперше вводиться до наукового обігу. Також використано раніше опубліковані матеріали відповідної тематики із

\footnotetext{
* Публікація містить результати досліджень, проведених у межах держбюджетної теми «Українська революція (1917 1921 pp.): селянський фактор» (номер державної реєстрації 0112U003864)
}

збірників документів, спогадів, хрестоматій, періодичних видань.

Найважливішою перевагою рецензованого збірника $є$ комплексний підхід, який дозволяє отримати цілісне уявлення про механізми вироблення, прийняття і функціонування аграрного законодавства на території України в революційну добу. Характерно, що упорядники не обмежилися публікацією документів, які стосуються лише власне українських державних утворень - першої та другої УНР, Української Держави та ЗУНР, але й залучили аграрну нормативну базу інших держав і політичних режимів, які в той час поширювали свій контроль на українську територію, або на її окремі регіони.

Так, у першій главі наведено десять документів, які характеризують земельну політику Тимчасового Уряду Росії, шоста глава містить 15 документів 3 царини совєтської аграрної політики, сьома глава охоплює 33 документи щодо формування аграрного законодавства Білого руху (Особливої наради ЗСПР й Уряду Півдня Росії), у восьмій главі опубліковано Закон Румунської держави про аграрну реформу для Бессарабії та Закон аграрної реформи в Буковині, дев'ята глава містить Акт Речі Посполитої від 15 липня 1920 р. про здійснення земельної реформи, а десята глава - Закон Чехословаччини від 11 червня 1919 p. про земельний уряд.

Серед документів Тимчасового Уряду привертають увагу нормативні акти, які мали регулювати створення і функціонування Земельних комітетів з підготовки і проведення земельної реформи, охорону посівів, матеріали Другого Всеросійського з'їзду Ліги агарних реформ, Закон про землю, ухвалений Всеросійськими установчими зборами тощо.

У главі присвяченій Українській Центральній Раді підібрані матеріали 3 рішень Першого Всеукраїнського військового з'їзду, Першого Всеукраїнського селянського з'їзду, Всеукраїнського робітничого з'їзду, нормативні документи Генерального секретаріату з земельних питань, фрагменти Універсалів УЦР, матеріали засідань Центральної Ради, текст Тимчасового земельного закону 18 січня 1918 р., у яких висвітлюється аграрна політика на першому етапі Української революції.

Глава про Гетьманат Павла Скоропадського містить Закон про право на врожай 1918 р. на території Української держави, Закон про право купівлі землі у сільській місцевості, Статут Державного Земельного банку, витяги із Закону про тимчасовий державний устрій України, матеріали засідань Ради міністрів Української Держави, проєкт загальних підстав земельної реформи, нормативні акти місцевих земельних комісій тощо. 
Документальна база доби Директорії представлена матеріалами засідань Ради Народних Міністрі, Декларацією Директорії УНР, постановами та розпорядженнями Директорії щодо аграрної проблематики, загальним планом проведення земельної реформи Народного Міністерства земельних справ від 16 січня 1919 р., інструкціями цього міністерства, текстом Закону про землю в УНР тощо.

П'ята глава збірника присвячена селянському законодавству Західноукраїнської народної республіки. Зокрема, подається інформація про підготовку аграрного законодавства на нараді щодо земельної реформи в Державному секретаріаті земельних справ, Ухвала земельної комісії Української національної Ради «Основи земельної реформи», текст Земельного Закону для $3 О$ УНР від 14 квітня 1919 р.

Серед матеріалів совєтської влади становлять інтерес «Манифест Временного рабочекрестьянского правительства Украины», резолюції з'їздів і пленумів ЦК КП(б)У та РКП(б) з селянського питання, витяги 3 «Земельного кодексу УСРР» 1922 р., текст Закону про землю 2 березня 1921 р.

Аграрне законодавство Особливої наради ЗСПР представлено постановами цієї інституції, зокрема щодо збору врожаю 1919 р., формуванню мирових комісій, Декларацією 3 аграрного питання від 23 березня 1919 р., положенням про відновлення прав власності на землю. Низка документів стосується діяльності комісії В. Колокольцева, комісії В. Челішева А. Білімовича з підготовки земельної реформи, звернень представників Всеросійського союзу земельних власників.

Подані також цікаві матеріали щодо аграрної політики Уряду Півдня Росії: урядові пояснення до Наказу про землю генерала П. Врангеля, про новий Земельний Закон, Тимчасове положення про земельні інституції, відомості про реалізацію Земельного Закону 25 травня 1920 р. тощо.

Отже, матеріали збірника дозволяють дослідникам отримати досить цілісну картину основних тенденцій регулювання аграрної сфери України революційної доби, зрозуміти підхід різних політичних сил щодо вирішення основного питання революції селянського. Наскрізною канвою, своєрідною червоною ниткою в тодішній аграрній політиці було проведення реформ, які дозволили б врегулювати земельну власність, ліквідувати або суттєво зменшити малоземелля селянства. Але окремі державні інституції та різні політичні гравці пропонували відмінні вектори та механізми їхнього проведення. Не важко побачити, що конкурентна боротьба за симпатії селянства спонукала частину політиків до популістських і спекулятивних кроків, які особливо помітні упідходах представників більшовицької влади. 3 іншого боку, більш реалістичні проєкти вирішення земельного питання запропоновані, скажімо, за гетьмана П. Скоропадського не знаходили належної підтримки, або не були реалізовані, оскільки їхні ініціатори втратили владу. Тим самим, дослідники можуть здійснити порівняльний аналіз адекватності нормативної бази та результативності аграрної політики різних державних угворень.

Як побажання можна запропонувати упорядникам збірника розширити його проблематику за рахунок залучення матеріалів 3 аграрної політики різних повстанських формувань, які діяли на території України, скажімо, «Революційної ради повстанців Херсонщини, Катеринославщини та Таврії», чи Ради Революційної повстанської армії України (махновців). Також не завадило б супроводити публікацію документів відповідними тематичними коментарями.

Зрештою, варто зауважити, що опубліковані документи i матеріали мають не тільки історіографічний характер, але й можуть становити суспільно-політичний інтерес для сучасної України, особливо в умовах впровадження ринку земель сільськогосподарського призначення.

Масненко В. В., доктор історичних наук, професор, завідувач кафедри історії України Черкаського національного університету імені Богдана Хмельнииького

ORCID: https://orcid.org/0000-0002-7825-3871

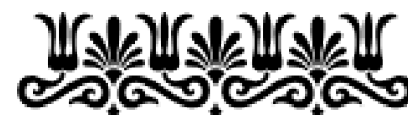

